\title{
Global Middle Ages: Eastern Wisdom (Buddhistic) Teachings in Medieval European Literature. With a Focus on Barlaam and Josaphat
}

\author{
Albrecht Classen $^{1}$ \\ ${ }^{1}$ University of Arizona, United States \\ Correspondence: Albrecht Classen, University of Arizona, United States.
}

Received: April 26, 2020; Accepted: June 25, 2020; Published: June 26, 2020

\begin{abstract}
In contrast to many recent attempts to establish concepts and platforms to study global literature, and this also in the pre-modern world, this article intends to present much more concrete examples to confirm that a certain degree of globalism existed already in the twelfth and thirteenth centuries. While numerous scholars/editors have simply invited many more voices from all over the world to the same 'table,' i.e., literary histories, which has not really provided more substance to the notion of 'global,' the study of translated texts, such as those dealing with Barlaam and Josaphat, clearly confirms that some core Indian ideas and values, as originally developed by Buddha, had migrated through many stages of translations, to high medieval literature in Europe.
\end{abstract}

Keywords: Global literature, medieval globalism, Barlaam and Josaphat, Jacobus de Voragine, Rudolf von Ems, the Laubacher Barlaam, literary translations, Buddhism in medieval Europe, Asia and Europe in the Middle Ages

\section{Introduction: Connections Between East and West}

Throughout the Middle Ages, knowledge about the Asian world was rather limited in Europe, although a good number of travelers, most famously, maybe, Marco Polo and Odorico da Pordenone, made their way to the Far East and later, after their return to the West, created detailed reports about their experiences. But we have searched so far in vain for data that might confirm the opposite movement, of Asians traveling to the West because of scientific, religious, medical, political, or artistic reasons. Nevertheless, considering the long history of Asian armies moving westward and achieving astounding successes, there must have been more knowledge about the European landscape and geo-political terrain available to the respective generals or leaders of the various armies to accomplish their goals so effectively.

Undoubtedly, the Huns, the Avars, the Magyars, and finally the Mongols were stunningly triumphant and moved amazingly quickly from East to West, which can have been possible only if they commanded excellent logistics and means of collecting data, as we know also from western armies, such as those in the Carolingian empire.[1] It is very probable, of course, that local guides were used, but the success of those invading troops would not have been possible without some global perspectives, strategic planning, and geographical knowledge on the part of the commanding officers. Those hostile forces even seem to have had a better understanding of the various countries where they suddenly appeared and attacked than the natives who did not know much about those enemies, had not traveled much beyond their parochial limits, and were probably familiar only with their localities.

However, all those nomadic attackers quickly disappeared again, and it is highly unlikely that the horrible military conflicts raised any interest by the victimized population to learn more about the East or to follow the receding armies in revenge. [2] In other words, no one tried to track them down after they had retreated, somewhere in Asia, for instance. At the same time, if we consider the example of the Vikings with their enormous scope from Newfoundland in the West to the Black Sea in the East, then we gain a certain hunch about the abilities of some peoples to travel far beyond their traditional homelands. [3]

If we jump from the early to the late Middle Ages, almost thousand years later, the situation does not seem to have changed dramatically at all, despite a flood of new travel experiences by pilgrims, merchants, and diplomats latest since the thirteenth and fourteenth centuries. Linguistic, political, cultural, and also economic hurdles made it very difficulties for the average European, even for those with a moderate degree of education, to reach out to eastern cultures. [4] Of course, there are exceptions, but those only seem to confirm the rule. The Bavarian slave Hans Schiltberger (1381-ca. 1440), for instance, once in Ottoman captivity, was moved around much over thirty years 
of forced military service and might have made his way as far north as modern-day Kazakhstan and as far south as Egypt. But, as a slave, he did not enjoy freedom, did not have the privilege of studying the cultural environment where he was stationed or had to fight, and so had little to say about the Asian world. [5] Granted, we learn much in his account about the Armenian kingdom, the Eastern Orthodox Church, and other aspects, but Schiltberger's perspectives were limited by default.

\section{Late Medieval Anti-Globalism: The Case of Fortunatus}

A few decades afterwards, the anonymous author of the early modern novel Fortunatus (printed in Augsburg in 1509) highlighted the central interest in traveling across the entire then known world, but he leaves out the eastern Asian continent and does not say anything specific about the local cultures and religions. Specifically, he confirmed that it would be an absurd assumption that Asians would have any interest in exploring Christian Europe because that western continent would simply not live up to their own cultural standards: "vnsre land vnaertig seyen / von keltin vnd auch nit guote frücht haben / hond sorg das sy gleich sturben" (491; [they believe that] our lands are hostile to them due to the cold and the lack of good food; they are afraid that they would die immediately). [6] The East Asian Indians would be regarded as fools if they decided to leave their own good lands to visit the bad lands in Europe; finally, they would know about the dangers of travel to the West; hence, it would not make sense for them to pursue any interest in Europe.

However, within the fictional framework, and with the help of the miraculous money purse which never empties, Fortunatus, at least, is able to make his way from Cyprus to Egypt, and from there to the Holy Land and then even India. The poet, of course, knows very little about it and only comments about the three parts which it consists of, and the huge size of the lands which far exceeds the large territories of the other mighty rulers in the world, including China and Egypt (490). Yet, just when the narrator has reached the point of going into details, he refrains from doing that and instead refers his audience to an outside source, here identified as Johann de Monteuilla (490), meaning John Mandeville, the famous armchair travelogue author, perhaps really Jean de Bourgogne (d. 1372). [7]

We might have to be careful in general concerning the validity of all medieval travelogues, fictional or factual, and thus might not gain much in regard to our search about possible familiarity with Buddhism and Asian culture in the European Middle Ages. [8] Even if an individual would have learned something about the foreign religion, it would have been extremely dangerous for him/her to relate something about that non-Christian faith since the Catholic Church would have responded rather aggressively.

Nevertheless, we have been called upon for quite some time to explore not only travelers and travelogues from that time period, but also to investigate the transcultural exchanges occurring during the pre-modern world, which involved numerous translations from Arabic to Hebrew, and then to Latin, which thus became the source for countless translations into the various vernaculars. [9] The literary, i.e., fictional, media was much more forgiving for opening up of new cultural perspective and for inviting in foreign cultures, laying the groundwork for much later actual contacts and visits, at least by Europeans going East. For instance, the first major vernacular account about India was delivered by Balthasar Sprenger (d. ca. 1511). [10]

\section{India in Medieval European Perceptions}

The world of India, for instance, was certainly firmly implanted on the minds of the learned Europeans, as numerous poets reveal who included specific references to that subcontinent. [11] India appears, of course, also on many mappaemundi, and there is no shortage of references to India in pre- and courtly romances, such as in the anonymous Herzog Ernst (ms. A ca. 1180; ms. B ca. 1220), [12] in Priest Lambrecht's Alexander (ca. 1190), [13] and in Wolfram von Eschenbach's Parzival, [14] to refer here to Middle High German literature where it seemed to have received more attention than elsewhere. Geographers and travelogue authors mentioned it, but there was a lot of confusion and ignorance about India proper during the Middle Ages. [15] Probing this issue further, we come certainly across, alas, medieval racist stereotypes and notions, and this well before the rise of modern-day racism, as Geraldine Heng has convincingly demonstrated on a global level. [16] But how else could that have been considering the lack of mutual contacts, mutual understanding, and mutual interest? There is no doubt that most Europeans viewed the rest of the world only through the lens of Christianity, and if they could imagine that a St. Thomas or the famous Prester John did his share in missionizing and converting people in the Asian continent, then the medieval audience was probably just content with the outcome as outlined in the literary works.

By the same token, we can be fairly certain about numerous intellectual and creative exchanges between East and West via literary channels, though concrete details and evidence still evade our full interpretive grasp. [17] The ancient Indian Panchatantra, composed by a Vishnu Sharma or Vasubhaga, later known as Kalila and Dimna, certainly exerted considerable influence on Persian, then Arabic, from there on Latin, and vernacular European 
literature, here not even taking into account the influence on the Far Eastern world. Composed sometime in the 3rd or 2 nd century B.C.E., or possibly as late as the 3 rd century C.E., this collection of short narratives containing messages about wisdom has survived in a large number of copies and then translations into many of the world's languages. [18]

Romedio Schmitz-Esser has recently attempted to trace specific evidence concerning the influence of Buddhism on the medieval West, or at least a certain degree of familiarity in the West of some aspects pertaining to that religion and culture. In order to trace the potential import of "ideas, of art, of material culture from Eastern and Southern Asia to medieval Europe" (322), he searches for the almost non-existing Asian traveler to the West, the well-known European travelers to the East, literary sources, such as the Legenda aurea, and finally Asian products which made their way to the western markets. [19] Indeed, in economic turns, there is a growing body of data confirming that East and West met especially in the region of the Black Sea, where the markets brought together European and Asian merchants, irrespective of the many military and political conflicts which often threatened to disrupt their trade. [20] Even though we might not consider merchants necessarily as the best informed and educated intellectuals who would have approached eastern wisdom literature with the eye of a philologist or philosopher, they were those who traveled the farthest and by default developed considerable linguistic and cultural skills to cope well in the foreign worlds where they found their best markets. And all merchants need entertainment after the closing of the shops, so they can be regarded as some of the most likely conveyers of Asian literature, art works, or music to the West, and vice versa.

\section{Barlaam and Josaphat}

One of the most striking examples of the intellectual exchange between East and West, that is, the translation of Eastern literature and religion into western languages, proves to be the story of Barlaam and Josaphat. In essence, this is the account of Buddha's early life as composed some time around the first century C.E., which was then exported both East and West via countless translations. [21] This popular story was a major theme also for a variety of courtly poets in medieval Europa, such as Rudolf von Ems, who created his Barlaam und Josaphat in ca. 12251230. At the same time, artists used the account about this young man Josaphat who fights his father over their religious orientations and can finally succeed in demonstrating the superiority of Christianity, in various media, such as in the frescoes applied to the interior walls of the Gozzoburg (Gozzo Castle) in Krems, Lower Austria. [22]

\section{Jacobus de Voragine}

In Jacobus de Voragine's Legenda aurea, composed around 1260 by this highly esteemed and very successful Dominican priest in Genoa (archbishop since 1292 until his death in 1298), we find one of the many versions of the story of this Indian saint, that is, in a way of Buddha himself, considering the critical experiences by the young protagonist as a wealthy prince whose father is trying in vain to keep him isolated away from all suffering and pain in this world, pretending to him that all life is filled with nothing but pleasure and happiness. [23]

The narrator does not discuss any of his ancient sources, refers only to the one used by him, a translation by John of Damascus in the tenth century, [24] but places us immediately within India where many people have converted to Christianity and are yet persecuted by King Avenir who adheres to the old faith. The Christian Church has developed there already so much that monasteries have been erected. When one of Avenir's high-ranking members of the court turns away from the world and joins a monastery, this arouses the king's extreme anger who has him fetched and questioned, and is thus informed about the essence of the Christian faith, which he rejects, however.

In the meantime, Avenir's son Josaphat is born, and when he inquires with his astrologers concerning the young boy's future, the wisest among them foretells that Josaphat would one day “ ". . . not reign in your kingdom but in an incomparably better one, because, as I see it, he will worship as a believer in Christ's religion, which you are persecuting!"' (356). This frightens the father, so he has his son raised in a remote and luxurious castle where no one is allowed to talk to him about old age or death. Anyone who is falling ill is immediately removed from the prince's presence.

However, young Josaphat tires of the complete isolation in the palace and is finally allowed to depart for a ride on horses. Here he suddenly encounters a leper and a blind man and is thus finally confronted with the reality of this world. Thereafter, he also meets an old man, thus learns about old age and also death, which throws him into deep thoughts and awakens profound desires to be instructed about those phenomena (358).

Soon thereafter, the monk Barlaam appears in the disguise of a merchant and is allowed to join the prince's company. This provides him with the opportunity to teach him lessons about Christianity and convince him of the truth of that faith. However, though Josaphat would have liked to join him in his hermitage, Barlaam urges him to wait for the right moment in the future. Then he baptizes his mentee and departs. Unfortunately for Josaphat, his 
father has learned about his conversion and is deeply grieved, looking for a strategy to change all that. In a conversation with his son, he learns the following: "Father, I fled the darkness and ran to the light, abandoned error and acknowledged the truth. Do not labor in vain, therefore!" (362). The king even threatens to disown him if he does not let go of his new faith, which fails to achieve anything. Next, the father tries kindness and love, which also does not work. Thereupon he offers to have a public debate between his own people and this Barlaam, whom he has allegedly apprehended, though this is the wrong man who actually cooperates with Avenir to deceive Josaphat about his new religion (Nachor).

Nachor, scared of Josaphat's threats against his life if he were to fail in his public defense of Christianity, tries his hardest to do just that and wins, against his own original intentions and the king's instruction. Surprisingly, Josaphat, who actually knows of his true identity, manages to convert Nachor to Christianity, and the latter then leaves the court and turns into a hermit (364). Next, the sorcerer Theodas attempts with the help of demons and a score of lovely ladies to seduce the prince, but although he is getting close to his goal due to the erotic lure, he ultimately fails as well, listens to Josaphat's teachings, and so also turns into a Christian.

Finally, the young man's father divvies up his kingdom and grants half of it to his son, who grudgingly accepts the position of a ruler because this allows him to erect churches and crosses and to have his people missionized and baptized into Christians. The narrative concludes with the father himself abandoning his old faith and accepting the new one: "Thereafter he devoted himself to good works and finished his life virtuously" (366). Josaphat tries several times to flee to get away from his worldly post, and finally manages it, wandering throughout the world until he finds Barlaam, with whom he then shares many years together until first the older man, than he himself dies. Both are honorably buried, and the account concludes with references to miracles which occurred at their graves.

\section{Other Asian and European Connections:}

\subsection{The Panchatantra}

We are not in a strong position to claim that the European poet was truly familiar with India or even with Buddhism, and yet the essential aspects of Buddha's life are still preserved here despite the many stages of translation, such as by Vincent of Beauvais. [25] However, if we adduce a quite parallel account contained in the Roman des sept sages de Rome, also translated into many languages, we recognize two strong strands of narrative traditions extensively popular both in the eastern world and in medieval Europe highlighting the central importance of wise advisors to a ruler who ultimately learns the path to Christian piety and a life of devotion and submission under God. [26] In the West, this was probably best illustrated by the Castilian poet Don Juan Manuel (1282-1348) in his famous collection of narratives, El Conde Lucanor (1335), parts of which can be traced back to the Panchatantra. [27]

Jacobus de Voragine did not engage intensively with India as such; instead, he focused on the experiences of the prince who has suddenly to face old age, sickness, and death, which transforms him deeply and opens the pathway toward his conversion to Christianity. Those experiences move him away from the illusions of his splendid life as the king's heir and confront him with the painful aspects of all physical reality. Those experiences, however, are so humbling, just as in the case of Buddha, that he ultimately abandons all the material wealth and turns into a hermit, together with his teacher and friend Barlaam.

We can easily refer to any of the many summaries of Buddha's life to recognize immediately the striking parallels:

His early life was one of luxury and comfort, and his father protected him from exposure to the ills of the world, including old age, sickness, and death. At age 16 he married the princess Yashodhara, who would eventually bear him a son. At 29, however, the prince had a profound experience when he first observed the suffering of the world while on chariot rides outside the palace. He resolved then to renounce his wealth and family and live the life of an ascetic. During the next six years, he practiced meditation with several teachers and then, with five companions, undertook a life of extreme self-mortification. One day, while bathing in a river, he fainted from weakness and therefore concluded that mortification was not the path to liberation from suffering. Abandoning the life of extreme asceticism, the prince sat in meditation under a tree and received enlightenment, sometimes identified with understanding the Four Noble Truths. [28]

Once the Indian version had made its way to Persia, from there to Armenia, Syria, and the Arab-speaking world, the account of Buddha's life spread also to medieval Europe, as exemplified by the various versions by, for instance, Gui de Cambrai (first half of the thirteenth century), by Catalan, Hebrew, Italian, and English translators, not to forget Latin and French versions. [29] Interestingly, as much as western audiences were deeply intrigued by this prince's personal decision to abdicate from his throne in order to live a life of virtues, spirituality, and purity, as 
much Buddha's story spread also to China, Vietnam, and Southeast Asia. In fact, if we want to approach the phenomenon of the global Middle Ages, or any other era on a global level, then the story of Barlaam and Josaphat provides the best evidence that such global connections actually existed. [30]

Whereas the poets of traditional courtly romances project a mostly generic physical background without any particular interest in translating - here understood in conceptual and mental-cultural terms - in the case of the highly popular story of this prince and his hermit-teacher we encounter a much more serious interest in some universal questions as they had been raised in the Indian context. Whether the poets/translators and their audiences had any concrete knowledge or concept of Buddhismus, or whether they simply found the account of self-imposed asceticism by a prince so appealing as a spiritual critique of power-hungry and pompous rulers within their own domain, does not have to be decided here. [31] What matters is only the fact that the world of Indian Buddhism is indirectly evoked here, especially because the ideals presented in this text appealed to audiences across medieval Europe. [32]

\subsection{Rudolf von Ems}

One of the most elaborate versions can be found in Rudolf von Ems's Barlaam und Josaphat (ca. 1230), who created this work upon the request of the Abbot Wido of the Cistercian monastery of Kappel near Zürich. [33] Wido wanted Rudolf, a ministerialis (administrator) at the court of the bishops of Constance, to translate the Latin origin by John of Damascus, Historia duorum Christi militum. Parallel to Rudolf and independently from him, two other Middle High German poets also created translations, the oldest being the Laubacher Barlaam, perhaps by Bishop Otto II of Freising (1184-1220). A third translation, also from the thirteenth century, has survived only in fragments. [34]

Rudolf's version obviously enjoyed considerable popularity, as documented by twenty-three manuscripts containing the full text, and twenty-eight manuscripts offering fragments. [35] There are strong parallels with the version in Jacobus de Voragine's Legenda aurea, but also differences. [36] Here, the king father is afraid that his son might convert to Christianity, and so he isolates him completely, surrounded only by young and healthy people who all look out for his entertainment and pleasures - Jacobus had only emphasized that Josaphat would rule in a much better kingdom than his father's. The subsequent events are fairly parallel, except that later, once the father has divvied up the kingdom so that his son can rule over his own part, political and economic aspects enter the picture. Surprisingly, Josaphat's kingdom, where Christianity has been introduced, prospers considerably, whereas the other half experiences a dramatic decline. After the father's death, Josaphat hands over the rule to his loyal servant Barachias and turns into a hermit himself. He finally encounters Barlaam and assumes, after his death, the government of the hermits' community. Barachias is identified as the one who has their story recorded and thus preserved for posterity. [37]

Rudolf made considerable efforts to expand on Jacobus's version, but he stayed close to it, after all. We are, however, given many more details, quotes from exchanges, and dramatic illustrations, especially of Josaphat's reaction to the encounter with the leper and the blind man. One of many examples would be that the young man is informed that no one here on earth can predict whether s/he will be inflicted by leprosy or any other illness, which indicates the complete contingency which all individuals here on earth are subjugated under (1214-19). The poet offers considerably more motivational insights and fleshes out whereas Jacobus is rather curt in his account, but otherwise, the Middle High German version proves to be very close to the one in the Golden Legends.

The Laubacher Barlaam draws much inspiration from the late antique tradition of the desert fathers, especially illustrated by the repeated references to St. Anthony. This work includes extensive didactic passages, such as Barlaam's elaborate instructions of his student Josaphat, the latter's intensive engagement with his father and the people about the proper faith, then the long explanations of some of the pagan religions, of the concepts by the Greeks concerning their gods, of the Egyptians' cult of plants, and other pseudo-scientific aspects, always distancing the Christian faith from the pagan cults. [38]

As far as I can tell, India, Buddhism, and East-Asian culture did not figure prominently anywhere else in medieval literature, even if we hear about India in other literary contexts determined by the account of Alexander the Great. [39] Nevertheless, the huge success story with Barlaam and Josaphat all over Europe and far beyond underscores that the theme itself, so closely associated with Buddha, exerted profound influence.

Reflecting on Jacobus de Voragine's Golden Legend once again, which set the tone for many European vernacular translations, we observe primarily that the narrator takes his audience to India as one of the many possible staging grounds for his story. There is no particular explanation for the reasons why he used this backdrop, except that the narrative set-up proved to be so appealing, with the conflict between father and son, the latter being converted to Christianity, which incenses the father immensely, although the narrator gives much praise to him early on as an 
admirable and wise ruler. But the outcome demonstrates that the Christian faith would triumph even under difficult circumstances. Most important proves to be that for the author/narrator Christianity had already made a major inroad into India, as documented by the presence of many converted individuals and also of a good number of monasteries. Josaphat's triumph at the end thus represents the complete victory of Christianity, although, which none of the western authors ever mentioned explicitly, the religious ideals presented here were really anchored in Buddhistic teachings.

\subsection{Marco Polo}

If we include also the perspectives and observations offered by Marco Polo in his famous Travels (ca. 1300), we can clearly observe the opaque approach to India, which he obviously visited, though without learning overly much about the various cultures and religions there. Most important for his attention was the political and military relationship of the local ruler with the Mongols, which was of a submissive kind. So we read: "this king renders the Great Khan every year a quantity of aloe wood and twenty elephants, the biggest and handsomest that can be found in his country. That is how he came to be the Great Khan's liege man and to pay him this tribute" (250). [40]

Similarly, the association of the Indian ruler and of the Indian masculine culture with extreme sexual control of the other gender also comes through loud and clear: "in this kingdom no pretty girl can marry without first being presented to the king for his inspection. If he is pleased with her, he takes her to wife. ... this king had 326 children, male and female" (250). As to the economics, Polo emphasizes, always being the merchant in his mind, that India produces mostly elephants, aloe wood, and ebony wood, and obviously nothing else (ibid.).

Apart from some exotic sounding references to various religious practices, the author does not allow his audience any further insights into the Indian culture, which voids his account of the desired anthropological information we would have liked to learn about. Of course, The Travels convey a much more vivid image of the world to the East as experienced by this extraordinary personality, but we cannot claim that Polo demonstrated particular awareness of and/or interest in the culture and spirituality practiced there. By the same token, the literary and religious works consulted above cannot claim any better authenticity, on the contrary. However, in light of the various versions of Barlaam and Josaphat we notice at least a strong interest to present a unique account about asceticism and piety as practiced by the hermit and then by his disciple, Josaphat.

The medieval audiences would not have mistaken them for accurate reports about India or Buddhism, the term of which was probably entirely unknown in Europe during the pre-modern era. At the same time, in all versions we clearly detect a strong sense of India as being a major battle ground where Christianity could become victorious and defeat the local pagan religions, and this by means of God's intervention helping Barlaam in his teaching of his princely disciple. In a way, we might even go so far as to read the various vernacular and the Latin versions as indirect criticism of the European rulers who did not perform the way how Josaphat did. Almost in a reversal of what Edward Said had called "Orientalism," these medieval poets demonstrated a kind of rudimentary Indiaphilia, a curious phenomenon particularly for an age very little informed about India itself. [41]

\section{Conclusion}

We can now conclude with some final reflections on the relevance of those works in which India is integrated as the essential battle ground for Christianity. As little as the various poets and their audiences could have really learned much about the eastern world through those reports which were predicated on the ancient Sanskrit texts reflecting the life of Buddha, as much do those works indicate a growth in global awareness. Whereas recent scholars have endeavored very hard to develop 'global literature,' 'globalism,' or similar universal concepts by way of simply allowing many different voices from around the world to come to the same table, here we face the unique opportunity to comprehend 'world literature' in a more meaningful way.

With respect to the Panchatantra, McComas Taylor observes insightfully:

The language and culture of earlier world literature was not imposed on audiences by the push-factors of colonial power. Rather, it was attracted by the pull-factors exerted by emergent elites. These include the Persian Sasanids who absorbed Indic culture, the recently Islamized Arbs who learned from the Persians, and the Spanish kings in Toledo and Greek elites in Constantinople who appropriated Middle Eastern scholarship.[42]

It seems, indeed, much more meaningful to trace themes, motifs, subject matters, and specific accounts as they unfolded across the world and made their influence felt wherever there was interest, for instance, in wisdom literature, than to assume that such global concepts as Orality, Heroism, Lyric Poetry, or Erotics and Politics of 
Love indeed allow us to claim global connections.[43] The issue at stake here is whether we want to aim for a pastiche or a collage, an integrated image or a kaleidoscope. It is one thing to identify a universal quest for knowledge, wisdom, and spiritual insights, if not even for mystical visions. It is a very different thing, by contrast, to trace connections, influence, translations, adaptations, summaries, paraphrases, imitations, or recreations across languages, cultures, and historical epochs. Azadeh Yamini-Hamedani observes, for instance, that "[m]ysticism in many respects is concerned with facing and overcoming limitations: be it the limitations of language or the entrapments of the self. Practices meant to invoke it, from rituals of devotion and meditation to asceticism or chanting, are all attempts in transcendence."[44] Would this, however, also entail that spiritualists and mystics from across the world would have automatically learned from it each other? Or did their visions and revelations simply follow similar epistemological patterns which allow us to place them side by side.

It is fully understandable that there are many attempts at writing global history and global literary history today in light of the actually ongoing globalization in the present time.[45] However, if those connections, parallels, identifications, or similarities in pre-modern literature exist in name only, and do not constitute deeply-seated intellectual, spiritual, and mental interaction, as I observe them in the vast tradition of Barlaam and Josaphat or in The Book of the Seven Sages (Historia septem sapientum), then the entire notion of global literature could be a rather shaky concept.[46] Even though we cannot claim that Jacobus de Voragine or Rudolf von Ems were intimately familiar with the Oriental origin of their tale, they explicitly situated it in India and predicated the religious and ethical concept on the ancient account of Buddha's life. They certainly ignored Buddha, and did not realize that they were actually engaging with the spiritual values and concepts of Buddhism, but in essence, their translation and adaptation efforts clearly signaled that the ideals presented here were those shared by poets and audiences in East and West. We thus confront in this case a phenomenal opportunity to probe more deeply what globalism might have meant already in the pre-modern world. These literary examples signal that there existed elements of globalism at least in the mind of some western poets and authors, although it seems highly unlikely that eastern literature was equally determined by an interest in the West.

\section{References}

[1] David S. Bachrach and Bernard S. Bachrach, "Military Intelligence and Long-Term Planning in the Ninth Century. The Carolingians and Their Adversaries," Mediaevistik 33 (2020): 89-111. See also Reaven Amitai, "Mamluk Espionage Among the Mongols and Franks," Asian and African Studies 22 (1988): 173-81; see also the contributions to Go Spy the Land: Military Intelligence in History, ed. Keith Neilson and B. J. C. McKercher (Westport, CT: Prager, 1992); cf. also Beyond Ambassadors: Consuls, Missionaries, and Spies in Premodern Diplomacy, ed. Maurits Ebben and Louis Sicking. Rulers\&elites, 19 (Leiden and Boston: Brill, 2021).

[2] Recent years have seen extensive new research on all those nomadic people, whether the Huns, the Avars, the Magyars, or the Mongols. See, for instance, Walter Pohl, The Avars: A Steppe Empire in Central Europe, 567822. Trans. from the German (3rd ed., 2015; Ithaca, NY, and London: Cornell University Press, 2018); Ruotsala, Antti, Europeans and Mongols in the Middle of the Thirteenth Century: Encountering the Other. Suomalaisen Tiedeakatemian Toimituksia, Humaniora, 314 (Helsinki: The Finnish Academy of Science and Letters, 2001); Timothy May, The Mongols. Past imperfect (Leeds: ARC Humanities Press, 2020).

[3] See now Sæbjørg Walaker Nordeide and Kevin J. Edwards, The Vikings. Past imperfect (Leeds: ARC Humanities Press, 2020); Vikings Across Boundaries: Viking-Age Transformations II, ed. Hanne Lovise Aannestad, Elise Naumann, Heidi Lund Berg, Hanne Lovise Aannestad, Unn Pedersen, and Marianne Moen. Culture, Environment and Adaptation in the North, 2 (New York and London: Routledge, 2020).

[4] See now the contributions to Travel, Time, and Space in the Middle Ages and Early Modern Time: Explorations of Worldly Perceptions and Processes of Identity Formation, ed. Albrecht Classen. Fundamentals of Medieval and Early Modern Culture, 22 (Berlin and Boston: Walter de Gruyter, 2018).

[5] Johann Schiltberger, The Bondage and Travels of Johann Schiltberger, a Native of Bavaria, in Europe, Asia, and Africa 1396-1427, trans. from the Heidelberg ms. ed. in 1859 by Karl Friedrich Neumann by J. Buchan Telfer. With notes by P. Bruun and a preface, introduction and notes by the translator and editor (London: Hakluyt Society, 1897); cf. also the recent edition: Hans Schiltberger, Als Sklave im Osmanischen Reich und bei den Tataren: 1394-? 1427, ed. Ulrich Schlemmer. Alte abenteuerliche Reiseberichte (Wiesbaden: Ed. Erdmann, 2008); and for a German translation, see Johann Schiltbergers Irrfahrt durch den Orient: Der aufsehenerregende Bericht einer Reise, die 1394 begann und erst nach über 30 Jahren ein Ende fand. Aus dem Mittelhochdeutschen übertragen und herausgegeben von Markus Tremmel. Bayerische Abenteuer (Taufkirchen: Via Verbis Bavarica, 2000). For recent studies, see Albrecht Classen, "Global Travel in the Late 
Middle Ages: The Eyewitness Account of Johann Schiltberger," Medieval History Journal 23.1 (2020): 1-28 (online at: https://doi.org/10.1177/0971945819895896); id., "The Topic of Imprisonment in Medieval German Literature: With an Emphasis on Johann Schiltberger's Account About his 30-Year Enslavement in the East," Studia Neophilologica (2020):

https://www.tandfonline.com/doi/full/10.1080/00393274.2020.1755362 (both last accessed on April 24, 2021).

[6] Quoted from Romane des 15. und 16. Jahrhunderts, ed. Jan-Dirk Müller. Bibliothek der frühen Neuzeit, 1 (Frankfurt a. M.: Deutscher Klassiker Verein, 1990), 385-585; here 491. For a review of the relevant research and the central topics, see Albrecht Classen, The German Volksbuch. A Critical History of a Late-Medieval Genre. Studies in German Language and Literature, 15 (Lewiston, NY, Queenston, and Lampeter: Edwin Mellen Press, 1995, reissued 1999), 163-83; cf. also Anne Simon, "The Fortunatus Volksbuch in the Light of Later Mediaeval Travel Literature," Fifteenth-Century Studies 12 (1987): 175-86; Hannes Kästner, Fortunatus - Peregrinator mundi: Welterfahrung und Selbsterkenntnis im ersten deutschen Prosaroman der Neuzeit. Rombach Wissenschaft - Reihe Litterae (Freiburg i. Br.: Verlag Rombach, 1990), 76-106; Albrecht Classen, "Die Welt eines spätmittelalterlichen Kaufmannsreisenden. Ein mentalitätsgeschichtliches Dokument der Frühneuzeit: Fortunatus," Monatshefte 86.1 (1994): 22-44; id., "The Crusader as Lover and Tourist: Utopian Elements in Late Medieval German Literature: From Herzog Ernst to Reinfried von Braunschweig and Fortunatus," Current Topics in Medieval German Literature: Texts and Analyses (Kalamazoo Papers 2000-2006), ed. Sibylle Jefferis. Göppinger Arbeiten zur Germanistik, 748 (Göppingen: Kümmerle, 2008), 83-102; id., "The Encounter with the Foreign in Medieval and Early Modern German Literature: Fictionality as a Springboard for Non-Xenophobic Approaches in the Middle Ages: Herzog Ernst, Wolfram von Eschenbach, Konrad von Würzburg, Die Heidin, and Fortunatus," East Meets West in the Middle Ages and Early Modern Times: Transcultural Experiences in the Premodern World, ed. Albrecht Classen. Fundamentals of Medieval and Early Modern Culture, 14 (Berlin and Boston: Walter de Gruyter, 2013), 457-87; id., "Fremdbegegnung, Dialog, Austausch, und Staunen: Xenologische Phänomene in der deutschen Literatur des Mittelalters. Vom Hildebrandslied bis zum Fortunatus," Mediaevistik 26 (2013): 183-206.

[7] See the comments by Jan-Dirk Müller, ed., Romane, 1210; as to Mandeville, see, for instance, Mary Campbell. The Witness and the Other World: Exotic European Travel Writing,400-1600 (Ithaca, NY, and London: Cornell University Press, 1988); and Kim Phillips, Before Orientalism: Asian Peoples and Cultures in European Travel Writing, 1245-1510. The Middle Ages Series (Philadelphia, PA: University of Pennsylvania Press, 2014); Eastward Bound: Travel and Travellers, 1050-1550, ed. Rosamund Allen (Manchester: Manchester University Press, 2004). For eastern, specifically Arabic perspectives, see Nizar F. Hermes, The [European] Other in Medieval Arabic Literature and Culture: Ninth-Twelfth Century AD. The New Middle Ages (New York and London: Palgrave Macmillan, 2015). For the text by Mandeville, see The Book of John Mandeville with Related Texts, ed. and trans. Ian Higgins (Cambridge, MA: Hackett Publishing, 2011).

[8] Shayne Aaron Legassie, The Medieval Invention of Travel (Chicago and London: The University of Chicago Press, 2017).

[9] Sonja Brentjes, Alexander Fidora, and Matthias M. Tischler, "Towards a New Approach to Medieval CrossCultural Exchanges," Journal of Transcultural Medieval Studies 1.1 (2014): 9-50; with an extensive bibliography.

[10] Die Meerfahrt: Balthasar Springers Reise zur Pfefferküste: mit einem Faksimile des Buches von 1509, ed. Andreas Erhard and Eva Ramminger (Innsbruck: Haymon-Verlag, 1998); Albrecht Classen, "India Perceived Through the Eyes of Sixteenth-Century Readers: Ludovico de Varthema's Bestseller on the Early Modern Book Markets-A Narrative Landmark of the Emerging Positive Evaluation of curiositas," Medievalia et Humanistica 40 (2015): 1-24.

[11] Albrecht Classen, "Indien: Imagination und Erfahrungswelt in Antike und Mittelalter," Mittelalter-Mythen, V. Ed. Ulrich Müller and Werner Wunderlich (St. Gall: UVK, 2008), 359-72; for early modern perspectives, see id., "India Perceived Through the Eyes of Sixteenth-Century Readers: Ludovico de Varthema's Bestseller on the Early Modern Book Markets-A Narrative Landmark of the Emerging Positive Evaluation of curiositas," Medievalia et Humanistica 40 (2015): 1-24.

[12] Herweg, Mathias, ed. Herzog Ernst: Mittelhochdeutsch / Neuhochdeutsch, ed. Mathias Herweg. In der Fassung B (Stuttgart: Philipp Reclam jun., 2019). 
[13] Lienert, Elisabeth, ed. Pfaffe Lambrecht: Alexanderroman. Mittelhochdeutsch / Neuhochdeutsch. Stuttgart: Reclam 2007).

[14] Wolfram von Eschenbach, Parzival. Studienausgabe, ed. Karl Lachmann (6th ed.), trans. into German by Peter Knecht, intro. by Bernd Schirok (Berlin and New York: Walter de Gruyter, 1998).

[15] U. Knefelkamp, “Indien," Lexikon des Mittelalter, vol. V: Hiera-Mittel bis Lukanien (Munich and Zurich: Artemis Verlag, 1991), 404-05.

[16] Geraldine Heng, The Invention of Race in the European Middle Ages (Cambridge: Cambridge University Press, 2018).

[17] East Meets West in the Middle Ages and Early Modern Times: Transcultural Experiences in the Premodern World, ed. Albrecht Classen. Fundamentals of Medieval and Early Modern Culture, 14. Berlin and Boston: Walter de Gruyter, 2013); D'Orient en Occident: les recueils de fables enchâssées avant les "Mille et une Nuits" de Galland; (Barlaam et Josaphat, Calila et Dimna, Disciplina clericalis, Roman des Sept Sages), ed. Marion Uhlig and Yasmina Foehr-Janssens. Cultural Encounters in Late Antiquity and the Middle Ages, 16 (Turnhout: Brepols, 2014); Die Figur des Herrschers in der Exempelliteratur - Transkulturelle Perspektiven, ed. Mechthild Albert and Ulrike Becker. Studien zu Macht und Herrschaft, 8 (Göttingen: V\&R unipress; Bonn University Press, 2020).

[18] The Pancatantra: The Book of India's Folk Wisdom, trans. Patrick Olivelle (Oxford: Oxford University Press, 1997). For a truly solid overview of the history of this famous collection and its reception, along with a great bibliography, see https://en.wikipedia.org/wiki/Panchatantra (last accessed on April 24, 2021). See now Nasrullah Munshi, Kalila and Dimna, trans. from the Persian by Wheeler Thackston (Indianapolis, IN, and Cambridge: Hackett Publishing Company, 2019). For a case of a late medieval German translation, see Albrecht Classen, "India, Persia, and Arabia in the Mind of a Late Fifteenth-Century German Author: Transcultural Experiences through the Literary Discourse. Antonius von Pforr and His Buch der Beispiele der Alten Weisen," Philological Quarterly 99.2 (2020): 119-45.

[19] Romedio Schmitz-Esser, "The Buddha and the Medieval West: Changing Perspectives on Cultural Exchange Between Asia and Europe in the Middle Ages," Travel, Time, and Space (see note 2), 311-30; for Asian textiles at least in the Byzantine world, see Jaroslav Folda, "The Use of Çintamani as Ornaments: A Case study in the Afterlife of Forms," Byzantine Images and Their Afterlives: Essays in Honor of Annemarie Weyl Carr, ed. Lynn Jones (Farnham: Ashgate, 2014), 183-204; see also Jens T. Wollesen, "East Meets West and the Problem with Those Pictures," East Meets West in the Middle Ages and Early Modern Times: Transcultural Experiences in the Premodern World, ed. Albrecht Classen. Fundamentals of Medieval and Early Modern Culture, 14 (Berlin and Boston: Walter de Gruyter, 2013), 341-88.

[20] Evgeny Khvalkov, The Colonies of Genoa in the Black Sea Region: Evolution and Transformation. Routledge Research in Medieval Studies, 11 (New York and London: Routledge, 2018); id., "Population de Caffa génoise à la lumière des livres comptables des années 1423-1424 et 1461-1462," Mediaevistik 33 (2020): $155-65$.

[21] Albrecht Classen, "Kulturelle und religiöse Kontakte zwischen dem christlichen Europa und dem buddhistischen Indien während des Mittelalters: Rudolfs von Ems Barlaam und Josaphat im europäischen Kontext." Fabula 41 (2000): 203-28; Constanza Cordoni, "Barlaam und Josaphat in der europäischen Literatur des Mittelalters," Ph.D. diss., Vienna, 2010. See also the contributions to Barlaam und Josaphat: Neue Perspektiven auf ein europäisches Phänomen, ed. Constanza Cordoni und Matthias Meyer (Berlin and Boston: Walter de Gruyter, 2015); Jacques Le Goff, In Search of Sacred Time: Jacobus de Voragine and The Golden Legend, transl. by Lydia G. Cochrane (2011; Princeton, NJ: Princeton University Press, 2014).

[22] Gertrud Blaschitz, "Farbiger Innenraum - genealogische Metapher? Barlaam- und Josaphat-Fresken in der Kremser 'Gozzoburg,," Farbe im Mittelalter: Materialität-Medialität - Semantik, ed. Ingrid Bennewitz and Andrea Schindler. Akten des 13. Symposiums des Mediävistenverbandes vom 1. bis 5. März 2009 in Bamberg (Berlin: Akademie Verlag, 2011), 159-74; eadem, “'Barlaam und Josaphat' als Vorlage für Wandmalereien in der Gozzoburg von Krems," Medium Aevum Quotidianum 57 (2008): 28-48. For critical comments, see Christian Opitz, "Die Wandmalereien im Turmzimmer der Kremser Gozzoburg. Ein herrschaftliches Bildprogramm des späten 13. Jahrhunderts," Österreichische Zeitschrift für Kunst und Denkmalpflege 62 (2008): 588-602. Andreas Zajic, Kulturgeschichte der Überlieferung im Mittelalter. Quellen und Methoden zur Geschichte Mittel- und Südosteuropas, ed. Elisabeth Gruber, Christina Lutter, Oliver Jens Schmitt (Cologne, Weimar, and Vienna: Böhlau Verlag, 2017), 294-300; but confer also Gertrud Blaschitz, "BBarlaam 
und Josaphat' im moldawischen Kloster Neamt, Neamt, Rumänien,” Barlaam und Josaphat: Neue Perspektiven auf ein europäisches Phänomen, ed. Constanza Cordoni und Matthias Meyer (Berlin and Boston: Walter de Gruyter, 2015), 21-42. I summarize here the overview provided by Romedio Schmitz-Esser, 327 , n. 49,328, n. 52 .

[23] Jacobus de Voragine, The Golden Legend: Readings on the Saints, trans. William Granger Ryan (Princeton, NJ: Princeton University Press, 1993), vol. 2, no. 180, 355-166. Jacobus de Voragine, La légende dorée, trans. from the French by Jean-Baptiste-Marie Roze (Paris: Citadelles \& Mazenod, 2008). See also the edition and German translation, Jacobus de Voragine, Legenda aurea: die Heiligenlegenden des Mittelalters. Hrsg., neu übersetzt und mit einem ausführlichen Anhang versehen von Matthias Hackemann (Cologne: Anaconda, 2008). For a pragmatic approach to our text sample, see Reading Medieval Latin with the Legend of Barlaam and Josaphat, ed. and supplied with commentary by Donka D. Markus. Michigan Classical Commentaries (Ann Arbor, MI: University of Michigan Press, 2018).

[24] Historiae animae utilis de Barlaam et Ioasaph, ed. Robert Volk. Die Schriften des Johannes von Damaskos, 6. Patristische Texte und Studien, 60-61 (Berlin and New York: Walter de Gruyter, 2006).

[25] Mattia Cavagna, "Barlaam and Josaphat in the 'legenda aurea' and the 'Miroir historia': A Tale Twice Framed," Barlaam und Josaphat (see note 15), 85-100.

[26] Die Historia von den sieben weisen Meistern und dem Kaiser Diocletianus. Nach der Gießener Handschrift 104 mit einer Einleitung und Erläuterungen, ed. Ralf-Henning Steinmetz. Altdeutsche Textbibliothek, 116 (Tübingen: Max Niemeyer, 2001). See also Obermaier, S. (2004). Das Fabelbuch als Rahmenerzählung: Intertextualität und Intratextualität als Wege zur Interpretation des Buchs der Beispiele der alten Weisen Antons von Pforr. Beihefte zum Euphorion, 48 (Heidelberg: Universitätsverlag Winter, 2004).

[27] Reinaldo Ayerbe-Chaux, El Conde Lucanor: Materia tradicional y originalidad creadora (Madrid: J. Porrúa Turanzas, 1975). Mario Cossío Olavide, “Algunos moros muy sabidores': Virtuous Muslim Kings in Examples 30 and 41 of 'El conde Lucanor'," Bulletin of Spanish Studies 97.2 (2020): 127-38; see also Maria Cecilia Ruiz, "Theft in Juan Manuel's El Conde Lucanor," Crime and Punishment in the Middle Ages and Early Modern Age: Mental-Historical Investigations of Basic Human Problems and Social Responses, ed. Albrecht Classen and Connie Scarborough. Fundamentals of Medieval and Early Modern Culture, 11 (Berlin and Boston: Walter de Gruyter, 2012), 247-80.

[28] Giuseppe Tucci, Joseph M. Kitagawa, and Frank E. Reynolds, "Buddhism," online at: https:/www.britannica.com/topic/Buddhism/The-life-of-the-Buddha; see also https:/www.diamondwaybuddhism.org/buddhism/buddha/; https://www.accesstoinsight.org/ptf/buddha.html (all last accessed on April 25, 2021). For a scholarly rendition, see Chikō Komatsu The Way to Peace: The Life and Teachings of the Buddha, trans. from the Japanese (Kyoto: Hōzōkan Publ. Co., 1989).

[29] Barlaam und Josaphat, ed. Cordoni and Meyer (see note 17).

[30] Toward a Global Middle Ages: Encountering the World Through Illuminated Manuscripts, ed. Bryan C. Keene (Los Angeles, CA: The J. Paul Getty Museum, 2019), 3-4.

[31] María Jesús Lacarra, "The Figure of the Ruler in 'Calila e Dimna' and the 'Exemplario contra los engaños y peligros del mundo'," Die Figur des Herrschers (see note 12), 53-71. She limits herself to the Spanish tradition and traces it back primarily to Arabic sources. But, as we know already, the lines of transmission often go much further back to Persia and then India; see José Manuel Pedrosa, "Los cuentos en la España medieval entre la voz y la lettra," Cuentística castellana medieval, ed. Marta Haro Cortés. Vol. 1: Origen, consolidación y evolución. Del 'Calila e Dimna' al 'Exemplario contra los engaños y peligros del mundo. Colección Parnaseo, 6 (Valencia: Universitat de València, 2013), 229-47 (easily accessible online at: http://parnaseo.uv.es/AulaMedieval/AulaMedieval.php?id=CuentosMedievales (last accessed on April 25, 2021).

[32] Constanza Cordoni, Barlaam und Josaphat in der europäischen Literatur des Mittelalters: Darstellung der Stofftraditionen - Bibliographie - Studien (Berlin and Boston: Walter de Gruyter, 2014).

[33] Helmut de Boor, Die höfische Literatur: Vorbereitung, Blüte, Ausklang 1170-1250. Geschichte der deutschen Literatur von den Anfängen bis zur Gegenwart, 2 (Munich: C. H. Beck, 1966), 176-87.

[34]““Barlaam'-Bruchstücke,” ed. Franz Pfeiffer, Zeitschrift für deutsches Alterthum 1 (1841): 126-35. Online at: https://www.jstor.org/stable/20649870?seq=1\#metadata_info_tab_contents (last accessed on April 25, 2021).

[35] The latest account is provided online at: https://handschriftencensus.de/werke/321 (last accessed on April 25, 
2021).

[36] Rudolf von Ems, Barlaam und Josaphat. Dichtungen des deutschen Mittelalters, 3. Nachdruck mit einem Anhang, einem Nachwort und einem Register von Heinz Rupp (Berlin: Walter de Gruyter, 1965); online at: https://www.digitale-sammlungen.de/en/view/bsb10107283?page=1 (last accessed on April 25, 2021).

[37] Joachim Bumke, Geschichte der deutschen Literatur im hohen Mittelalter (Munich: Deutscher Taschenbuch Verlag, 1990), 394-95.

[38] Helmut de Boor, Die deutsche Literatur im späten Mittelalter. Part I: 1250-1350. 5th ed. Newly revised by Johannes Janota. Geschichte der deutschen Literatur von den Anfängen bis zur Gegenwart, III/1 (1962; Munich: C. H. Beck, 1997), 459-61.

[39] Alexanderdichtungen im Mittelalter: Kulturelle Selbstbestimmung im Kontext literarischer Beziehungen, ed. Jan Cölln, Susanne Friede, and Hartmut Wulfram. Veröffentlichungen aus dem Göttinger Sonderforschungsbereich 529 “Internationalität nationaler Literaturen”, 1 (Göttingen: Wallstein Verlag, 2000).

[40] The Travels of Marco Polo, trans. and with an intro. by Ronald Latham (London: Penguin, 1958); for recent critical studies, see the contributions to Marco Polo and the Encounter of East and West, ed. Suzanne Conklin Akbari and Amilcare Iannucci (Toronto, Buffalo, and London: University of Toronto Press, 2008). One of the best studies continues to be by John Larner, Marco Polo and the Discovery of the World (New Haven, CT, and London: Yale University Press, 1999); cf. also Albrecht Classen, "Marco Polos Il Milione/Le Divisement du Monde: der Mythos vom Osten," Mittelalter Mythen. Herrscher, Helden, Heilige. Ulrich Müller and Werner Wunderlich, eds. (St. Gall: UVK, 1996), 423-36; id., "Marco Polo and John Mandeville: The Traveler as Authority Figure, the Real and the Imaginary," Authorities in the Middle Ages: Influence, Legitimacy, and Power in Medieval Society, ed. Sini Kangas, Mia Korpiola, and Tuija Aionen. Fundamentals of Medieval and Early Modern Culture, 12 (Berlin and Boston: Walter de Gruyter, 2013), 239-48.

[41] Edward Said, Orientalism (London: Routledge, 1978); Khanmohamadi, Sh. A., In Light of Another's Word: European Ethnography in the Middle Ages. The Middle Ages Series (Philadelphia, PA: University of Pennsylvania Press, 2014).

[42] McComas Taylor, "The Panchatantra: World Literature Before 'World Literature," A Companion to World Literature, ed. Ken Seigneurie. Vol. 1: Third Millennium BCE to 600 CE, ed. Wiebke Denecke and Ilaria L. E. Ramelli (Hoboken, NJ, and Chichester, West Sussex: John Wiley \& Sons, 2020), 561-75; here 572.

[43] This is, as I see it, the major problem with the six-volume set, A Companion to World Literature (see note 35). Cf. also Roland Wenzlhuemer, Doing Global History: An Introduction in Six Concepts (London: Bloomsbury Academic, 2020). Salisbury, J. E., ed. (2009). The Greenwood Encyclopedia of Global Medieval Life and Culture. 3 vols (Westport, CT, and London: Greenwood, 2009); Heng, G., and Ramey, L. (2014). Early Globalities, Global Literatures: Introducing a Special Issue on the Global Middle Ages. Literature Compass, 1-6; online at: 10.1111/lic3.12156;

[44] Azadeh Yamini-Hamedani, “On Transcendence and Literariness," A Companion to World Literature (see. note 35), vol. 2, 774-82; here 776.

[45] Forde, Simon. The Encyclopedia of the Global Middle Ages. London: ARC Humanities Press, 2019; online at: https://www.bloomsburymedievalstudies.com/encyclopedia?docid=b-9781350990005.

[46] Die Historia von den sieben weisen Meistern und dem Kaiser Diocletianus (see note 22); see also Le roman des sept sages, ed. Jean Misrahi. Rpt. (1933; Geneva: Slatkine, 1975); Le roman de Dolopathos: edition du manuscrit H 436 de le Bibliothèque de l'Ecole de Médecine de Montpellier, ed. Jean-Luc Leclanche. Les classiques français du Moyen Âge, 126 (Paris: Champion, 1997).

\section{Copyrights}

Copyright for this article is retained by the author(s), with first publication rights granted to the journal.

This is an open-access article distributed under the terms and conditions of the Creative Commons Attribution license (http://creativecommons.org/licenses/by/4.0/). 